\title{
Proximate Composition and Consumers' Subjective Knowledge of Deep Fat Fried Chin-Chin and Functional Properties of the Wheat-Cassava Composite Flour Used
}

\author{
Innocent Nwazulu Okwunodulu1,a,*, Judith Ucheoma Iloka ${ }^{1, b}$, Geraldine Kasie Okakpu', \\ John Chidiebere Okakpu',d \\ ${ }^{1}$ Department of Food Science and technology, College of Applied Food Sciences and Tourism, Michael Okpara University of Agriculture, \\ Umudike, Abia State Nigeria. \\ *Corresponding author
}

\begin{tabular}{|c|c|}
\hline A T I C L E I N F O & A B S T R A C T \\
\hline $\begin{array}{l}\text { Keywords: } \\
\text { Chin-chin } \\
\text { Deep fat frying } \\
\text { Composite flour } \\
\text { Wheat flour } \\
\text { Cassava flour }\end{array}$ & $\begin{array}{l}\text { Due to high cost of importation and inability of wheat to thrive in Nigeria, baked products like chin- } \\
\text { chin are costly and out of the reach of common people. Since baked products are convenient snack } \\
\text { relished by all, substitution with readily available materials like cassava flour becomes the only } \\
\text { available option. Wheat and cassava flours were blended in the ratios of } 70: 30 \%, 50: 50 \% \text { and } 30 \text { : } \\
70 \% \text { respectively while } 100 \% \text { wheat and cassava flours served as controls. Deep fat fried chin-chin } \\
\text { samples were prepared from the blends. Proximate and functional properties were conducted on the } \\
\text { flour blends while proximate composition and acceptability test were on the chin-chin samples. The } \\
\text { results revealed that with increase in cassava inclusion levels in the composite flour blends, there } \\
\text { was increase in moisture }(7.77-8.23 \%) \text {, carbohydrate }(73.42-79.23 \%) \text {, ash }(0.75-1.00 \%) \text {, bulk } \\
\text { density }(0.51-0.61 \text { g/ml), swelling index (0.96.1.09\%), water absorption capacity }(1.10-1.88 \mathrm{~g} / \mathrm{g}) \text {, } \\
\text { and emulsion capacity }(27.41-39.48 \%) \text { while dry matter }(91.20-9.84 \%) \text {, protein }(8.55-6.55 \%) \text {, fat } \\
(2.08-0.98 \%) \text {, fibre }(2.53-2.20 \%) \text { and oil absorption capacity }(1.29-1.16 \text { g/g) decreased. For chin- } \\
\text { chin, there was significant increase in moisture }(8.29-10.40 \%) \text { and carbohydrate }(63.63-66.54 \%) \\
\text { while dry matter ( } 91.70-89.59 \%) \text {, protein }(6.66-3.50 \%) \text {, fat }(17.57-16.84 \%) \text {, ash }(1.88-1.38) \text { and } \\
\text { fiber ( } 1.96-1.69 \%) \text { decreased. There was no significant difference in the overall acceptability of the } \\
\text { chin-chin samples. Therefore, cassava flour substitution of up to } 70 \% \text { is acceptable, but with } \\
\text { decrease in most of the nutrient composition which can be improved with lower }(<30 \%) \text { cassava } \\
\text { substitution levels. }\end{array}$ \\
\hline
\end{tabular}

\footnotetext{
nncntokwu@yahoo.com (iD) https://orcid.org/0000-0003-4156-8148 kasiegeraldine@gmail.com (iD https://orcid.org/0000-0002-9683-432X

\section{Introduction}

Chin-chin is a deep-fat-fried snack produced from unleavened dough prepared from wheat flour kneaded with water and ingredients such as sugar, milk, egg among others according to choice. The dough is pressed and cut into thin slices of different shapes like small squares and long stripes before frying (Mepba et al., 2007). Deep-fatfrying is suitable for food of all shapes; irregularly shaped foods tend to retain greater volume of oil when removed. During deep-fat-frying, all the chin-chin surfaces receive equal heat treatment to produce uniform colour and appearance (Fellows, 1997) because they are all immersed entirely into the hot oil. Many efforts have been made to promote the use of composite flours from partially substituted wheat flour with locally grown crops in pastry products to save importation cost (Olaoye et al., 2016). The use of wheat-cassava flour in chin-chin production will diversify cassava uses, enhances cassava production and value addition.

Wheat (Triticum aestivum) flour (hard and soft) has been the major ingredient for producing deep fat fried pastry products. Wheat provides nearly $78.10 \%$ carbohydrate, $14.70 \%$ protein, $2.10 \%$ fat, $2.10 \%$ minerals (zinc, iron, selenium and magnesium) and considerable proportions of vitamins B complex (Adams et al., 2002; Topping, 2007). 
Cassava (Manihot esculenta Gramtz) is a major root crop and an important staple food for over 500 million people in the developing world (Falade and Akingbala, 2010). Cassava pulp which represents about 10 to $15 \%$ of the root (Thongkratok et al., 2010) contains 60 to $70 \%$ moisture content and $50 \%$ carbohydrates on a dry weight basis. Dried cassava pulp is low in protein (approximately2\%), deficient in carotene and has high levels of insoluble fibre (Aro et al., 2008).

Wheat-cassava composite flour is wheat flour partially substituted with cassava flour for the production of leavened bread, unleavened baked products, porridges, pastas and snack foods such as chin-chin. Formally, only few types of flour (sorghum, or maize) is being used for the substitution for economical and nutritional purposes, but today several composite flours like millet-wheat, wheatplantain, wheat-soybeans, wheat-African yam beans, and wheat-cassava have been documented (Anon, 2000; Adegunwa et al., 2014).

Deep fat fried foods have been known for its satisfying crunchy, texture and its distinctive taste which are widely enjoyed. Globally, snacks are widely relished among kids and adults because of their convenience and distinctive taste. Chin-chin is popular in West Africa, including Nigeria with high demand as it is highly relished on by adults and kids because of their sweet crunchy, crispy and convenience. This study is aimed at evaluating the proximate and functional properties of different substitution levels of wheat-cassava flours and their effects on the proximate composition and acceptability of deepfat-fried chin-chin made from them.

\section{Materials and Methods}

\section{Material Procurement}

Wheat flour and the other ingredients used in this research were purchased from Ubani main market in Umuahia North Local Government Area while the cassava tubers were procured from the National Root Crops Research Institute Umudike (NRCRI) in Ikwuano Local Government Area, all in Abia State, Nigeria.

\section{Production of Cassava Flour}

The cassava tubers were sorted, peeled and washed in clean water to remove dirt. The cleaned tubers were grated with a grating machine and dewatered with the aid of a screw jack to obtain a semi-solid cassava cake. The cake was manually pulverized and dried in oven to constant weight, milled and sieved to obtain the fine flour. The flour was packaged in an air tight glass container.

\section{Formulation of Wheat-Cassava Composite Flour}

Wheat flour was partially substituted with cassava flour as in table 1 while $100 \%$ wheat and cassava flours served as controls.

\section{Preparation of Chin-chin}

Chin-chin was prepared according to Adegunwa et al. (2014). The composite flour blend, sugar, margarine, baking powder, egg and milk were measured into a $20 \mathrm{~L}$ stainless steel bowl and mixed thoroughly together before kneading with water into dough. The dough formed was placed on floured board surface and further kneaded into smooth and elastic dough which was rolled with a wooden roller to about $2 \mathrm{~cm}$ thick and cut with stainless knives into $2 \mathrm{~cm}$ by $6 \mathrm{~cm}$ sizes. The slices were deep-fat-fried in hot vegetable oil (about $180^{\circ} \mathrm{C}$ ) with open pan for about $8 \mathrm{~min}$ until golden colour was attained. The fried chin-chin was removed and allowed to drain off excess oil before cooling and packing in air tight polyethylene film for analysis (Figure 1). Same process was repeated for both the controls and all the composite flour blends.

Table 1. Blending ratios of wheat-cassava composite flour

\begin{tabular}{l|cc}
\hline \multicolumn{1}{c|}{ Sample } & Wheat (\%) & Cassava (\%) \\
\hline A & 100 & 0 \\
B & 0 & 100 \\
C & 50 & 50 \\
D & 70 & 30 \\
E & 30 & 70 \\
\hline
\end{tabular}

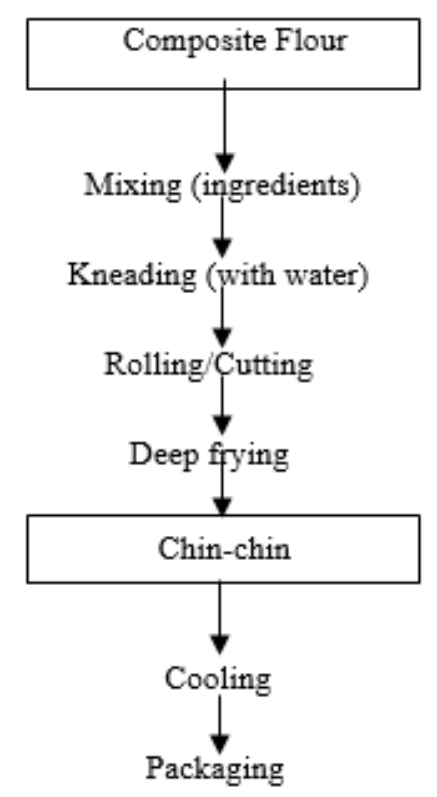

Figure 1. Flowchart for the preparation of Chin-chin

\section{Proximate Composition}

This was conducted on both the chin-chin and flour samples. The method of AOAC (2010) was used to determine moisture content (MC), ash, protein, fat and crude fibre, while carbohydrate was determined using the method of James (1995). The dried matter (DM) was calculation as

$\% \mathrm{DM}=100-\% \mathrm{MC}$

\section{Functional Properties}

The method of Onwuka (2018) was used for the analysis of bulk density, swelling index, oil absorption capacity, water absorption capacity and emulsion capacity of all the flour samples.

\section{Analysis}

\section{Sensory Analysis}

The method described by Iwe (2002) was used. The chin-chin samples were evaluated by 25 semi-trained panelists drawn from both male and female students of 
Department of Food Science and Technology, Michael Okpara University of Agriculture aged between 17-30 years. They were instructed to taste the samples and rate them using a nine-point Hedonic scale where 1 represents dislike extremely, 9 represents like extremely and 5 represents neither like nor dislike. Appearance, crispness, taste and aroma of the chin-chin samples were evaluated.

\section{Statistical Analysis}

Data obtained from all the analyses were subjected to analysis of variance (ANOVA) of a completely Randomized design (CRD) using SPSS version 20.Treatment means were separated using Duncan Multiple Range Test (DMRT) at 95\% confidence level $(\mathrm{P}<0.05)$.

\section{Results and Discussion}

\section{Proximate composition of wheat-cassava chin-chin samples}

The results are presented in Table 2.

Moisture content (MC)

The MC of the chin-chin samples $(8.29-10.40 \%)$ increased significantly $(\mathrm{P}<0.05)$ more than the controls (7.05 and $7.61 \%$ ) with increase in cassava flour inclusion. This may be due to significant $(\mathrm{P}<0.05)$ higher MC (Table 3 ) and water absorption capacity (WAC) in Table 4 of cassava than wheat flour. This is reflected in the significant ( $\mathrm{p}<0.05)$ higher M C $(7.61 \%)$ of chin-chin from $100 \%$ cassava flour than $100 \%$ wheat $(7.05 \%)$. The values were higher than $3.98-5.04 \%$ reported by Adegunwa et al. (2014) for Chin-chin made from millet-wheat composite flour. Sample D (70\% wheat: $30 \%$ cassava flour) with $8.29 \%$ MC may likely have better shelf stability (Sanni et al., 2006) and crispiness than the counterparts at same storage conditions.

Dry matter (DM)

The DM content of chin-chin increased significantly $(\mathrm{P}<0.05)$ with decrease in cassava flour in the flour blends. This could be as a result of significant $(0<0.05)$ higher MC of cassava flour than wheat (Table 3) which correlates inversely with DM. This is evident in the significant $(\mathrm{P}<0.05)$ higher DM $(92.94 \%)$ of sample A $(100 \%$ wheat $)$ than B (100\% cassava) with $92.38 \%$. Also, the least value (89.59\%) of sample E (30\% wheat: $70 \%$ cassava) testified that. As DM is an indication of the food mass, samples with lower levels of cassava will have more mass.

\section{Protein}

Significant $(\mathrm{P}<0.05)$ protein decrease $(6.66-3.50 \%)$ with increase in cassava inclusion in the blend could be attributed to lower protein content of the cassava flour than wheat (Table 3) which tends to lower the protein content of the chin-chin. This is attested by higher protein content $(7.16 \%)$ of sample A (100\% wheat) than B (100 percent cassava) with $2.81 \%$. The protein content of all the chin-chin from composite flour is lower than that from $100 \%$ wheat flour, but higher than that of $100 \%$ cassava flour. Chin-chin from $100 \%$ wheat flour with high protein content could be of nutritional importance in most developing countries like Nigeria where many people can hardly afford high proteinus foods because of their high cost.

Fat

Fat content of sample A (100\% wheat) is significantly $(\mathrm{P}<0.05)$ higher than $\mathrm{B}(100 \%$ cassava). This could be traced to higher fat content of wheat flour than cassava (Table 3) and higher oil absorption capacity (OAC) of wheat flour than cassava (Table 4). Similar decreasing fat content of chin-chin was also evident in the entire samples produced from composite flours from $17.57 \%$ in sample D (70\% wheat: $30 \%$ cassava) to 16.84 in sample E $(30 \%$ wheat: $70 \%$ cassava) as the cassava proportion in the blends increased. However, the fat content results of the entire chin-chin samples from the composite flours (16.84$17.57 \%$ ) were higher than 7.56 to $8.13 \%$ reported by Adegunwa et al. (2014) for Millet-wheat composite flour. Varietal wheat difference and variation in fat content of cassava and millet may be the major sources of variations. Non-significant $(\mathrm{P}>0.05)$ fat variation between samples $\mathrm{C}$ (50\% wheat: $50 \%$ cassava) and D (70\% wheat: $30 \%$ cassava) could suggest significant $(\mathrm{P}<0.05)$ fat content decrease as from $50 \%$ and above cassava inclusion level.

Ash

Ash content of the chin-chin decreased with increase in cassava proportion in the blends. The decrease could be attributed primarily to lower ash content of the cassava flour than that of the wheat as evident in the significant $(\mathrm{P}<0.05)$ higher ash content of sample A $(100 \%$ wheat $)$ than B (100\% cassava). The decrease was only significant $(\mathrm{P}<0.05)$ at higher level $(>50 \%)$ of cassava inclusion which suggested that lower $(<30 \%)$ cassava inclusion levels, result in higher iron content of the chin-chin. Ash content is an approximation of the mineral contents of food product.

\section{Crude fiber (CF)}

There were significant $(\mathrm{P}<0.05)$ crude fibre decrease (1.96-1.69\%) of the chin-chin samples with increase in cassava inclusion levels in the composite blends. The values were significantly $(\mathrm{P}<0.05)$ lower than $2.31 \%$ from $100 \%$ wheat and $2.17 \%$ from $100 \%$ cassava flours. The decrease could be improved with lower level $(<30 \%)$ of cassava inclusion to avoid compromising the health benefit of fiber. Fiber prevents obesity, constipation, hemorrhoids, cardiovascular diseases (Nzelu et al., 2012).

Table 2. Proximate composition of wheat-cassava Chin-chin (\%)

\begin{tabular}{l|ccccccc}
\hline Sample & Moisture & Dry Matter & Protein & Crude fat & Ash & Crude fibre & CHO \% \\
\hline A & $7.05^{\mathrm{e}} \pm 0.09$ & $92.95^{\mathrm{a}} \pm 0.09$ & $7.16^{\mathrm{a}} \pm 0.01$ & $18.74^{\mathrm{a}} \pm 0.01$ & $2.45^{\mathrm{a}} \pm 0.02$ & $2.31^{\mathrm{a}} \pm 0.01$ & $61.77^{\mathrm{e}} \pm 0.08$ \\
B & $7.61^{\mathrm{d}} \pm 0.02$ & $92.39^{\mathrm{b}} \pm 0.02$ & $2.81^{\mathrm{e}} \pm 0.05$ & $18.26^{\mathrm{b}} \pm 0.02$ & $2.15^{\mathrm{b}} \pm 0.02$ & $2.17^{\mathrm{b}} \pm 0.01$ & $62.67^{\mathrm{d}} \pm 0.12$ \\
C & $9.22^{\mathrm{b}} \pm 0.01$ & $90.78^{\mathrm{d}_{0}} \pm 0.04$ & $5.38^{\mathrm{c}} \pm 0.02$ & $16.95^{\mathrm{c}} \pm 0.02$ & $1.48^{\mathrm{c}} \pm 0.01$ & $1.80^{\mathrm{d}_{0}} \pm 0.02$ & $65.26^{\mathrm{b}} \pm 0.09$ \\
D & $8.29^{\mathrm{c}} \pm 0.02$ & $91.71^{\mathrm{c}} \pm 0.02$ & $6.66^{\mathrm{b}} \pm 0.03$ & $17.57^{\mathrm{c}} \pm 0.02$ & $1.88^{\mathrm{c}} \pm 0.02$ & $1.96^{\mathrm{c}} \pm 0.00$ & $63.63^{\mathrm{c}} \pm 0.09$ \\
E & $10.40^{\mathrm{a}} \pm 0.01$ & $89.60^{\mathrm{e}} \pm 0.01$ & $3.50^{\mathrm{d}} \pm 10.05$ & $16.84^{\mathrm{d}} \pm 0.00$ & $1.38^{\mathrm{d}} \pm 0.01$ & $1.69^{\mathrm{e}} \pm 0.01$ & $66.54^{\mathrm{a}} \pm 0.04$ \\
LSD & 0.537 & 0.158 & 0.114 & 0.092 & 0.069 & 0.044 & 0.290 \\
\hline
\end{tabular}

Values are means of triplicate determinations + standard deviation. Means in the same column with different superscript are significantly different (P <0.05). LSD: Least Significant Difference. $A=100 \%$ wheat, $B=100 \%$ cassava, $C=50 \%$ wheat $+50 \%$ cassava, $D=70 \%$ wheat $+30 \%$ cassava and $\mathrm{E}=30 \%$ wheat $+70 \%$ cassava. 


\section{Carbohydrate}

The carbohydrate content of the chin-chin samples increased $(63.63-66.54 \%)$ significantly $(\mathrm{P}<0.05)$ with increase in cassava inclusion in the composite blends. The increase could stem from higher carbohydrate content of the cassava flour than wheat (Table 3) which reflected same in their respective chin-chin samples. The carbohydrate content of the chin-chin from the composite flours was significantly higher than those of their control counterparts with that from $100 \%$ cassava higher $(62.67 \%)$ than that of $100 \%$ wheat flour $(61.79 \%)$. Sample E $(30 \%$ wheat: $70 \%$ cassava) had the highest value while sample D (70\% wheat: $30 \%$ cassava) had the least value. The carbohydrate content of the chin-chin samples from composite flours was higher than $57.40-63.35 \%$ reported by Adegunwa et al. (2014) for chin-chin from millet-wheat composite flour. This could be attributed to the blending ratio and carbohydrate content of the millet used.

\section{Proximate Composition of Wheat-cassava Composite Flour}

The results are shown in Table 3.

\section{Moisture content (MC)}

The moisture contents of the cassava flour is significantly $(\mathrm{P}<0.05)$ higher $(9.57 \%)$ than that of wheat with $8.49 \%$. Despite this, there was no significant $(\mathrm{P}>0.05)$ moisture variations among the entire composite flours blended out of them. May be the variations had no significant $(\mathrm{P}<0.05)$ effect on the MC of the composite flours. However, the MC of $<10 \%$ for all the flour samples signified shelf stability provided they stored in air-tight containers.

\section{Dry matter $(D M)$}

There was significant $(\mathrm{P}<0.05) \mathrm{DM}$ variations between the wheat $(91.51 \%)$ and cassava $(90.44 \%)$ flour samples. The variation also reflected in the composite flour blends formulated from them. The DM of the composite flours decreased with increase in cassava inclusion levels. This is evident in sample D (70\% wheat: $30 \%$ cassava) with the highest $(91.20 \%)$ value while $\mathrm{E}$ (30\% wheat: $70 \%$ cassava) had the least $(90.84 \%)$. As DM is the remaining nutrient after removal of moisture, increase in cassava levels may likely reduce the nutrient content of the composite flours.

Crude protein $(\mathrm{CP})$

The protein content of the composite flour samples decreased with increase in cassava inclusion levels as a result of significant $(\mathrm{P}<0.05)$ higher protein content of wheat (12.24\%) than cassava (4.92\%). Non-significant $(\mathrm{P}>0.05)$ protein variation between sample $\mathrm{C}$ (50\% wheat: $50 \%$ cassava) and $\mathrm{E}(30 \%$ wheat: $70 \%$ cassava) may suggest that significant protein decrease could be feasible only between $50-70 \%$ cassava inclusion and above. This is justified by significant $(\mathrm{P}<0.05)$ higher protein content $(8.06 \%)$ of sample D (70\% wheat: $30 \%$ cassava) than the rest composite flours. Wheat protein is needed for better dough formation. Similar protein reduction had been reported by Olaoye et al. (2007) for wheat: breadfruit flour and wheat: plantain blends by Mepba et al. (2007).

\section{Fat}

The significant $(\mathrm{P}<0.05)$ higher fat content of wheat flour $(2.21 \%)$ than cassava $(0.71 \%)$ may be the primary reason why the fat content of their composite flours decreased with increase in cassava inclusion. The decrease is from $2.08 \%$ in sample D (70\% wheat: $30 \%$ cassava) to $0.98 \%$ in E (30\% wheat: $70 \%$ cassava). Non-significant ( $\mathrm{P}>0.05)$ fat content variations between samples B $(100 \%$ cassava) and E (30\% wheat: $70 \%$ cassava) signified maximum fat reduction at $70-100 \%$ cassava inclusion in the composite flour blend. Oluwamukomi et al. (2010) reported same decreasing trend with increase in cassava flour inclusion in wheat: cassava composite flour.

Ash

The ash content of the composite flour samples increased significantly $(\mathrm{P}<0.05)$ with increase in cassava flour due to higher ash content $(1.39 \%)$ of cassava flour than wheat $(1.09 \%)$ which are not significant. Nonsignificant $(\mathrm{P}>0.05)$ ash content variation between samples C (50\% wheat: $50 \%$ cassava) and E (30\% wheat: $70 \%$ cassava) suggest maximum increase as from $70 \%$ cassava inclusion. The ash content results of this study is at variant with that of Oluwamukomi et al. (2010), who reported decrease with increase in cassava flour inclusion. Cassava variety may be the major cause.

\section{Crude fibre}

With increase in cassava flour inclusion, there was maximum fiber content decrease $(2.20 \%)$ at $70 \%$ and minimum $(2.54 \%)$ at $30 \%$ level of inclusion. The decrease was significantly $(\mathrm{P}<0.05)$ lower than control A $(100 \%$ wheat). However, these values (2.20-2.53\%) obtained in this study were within the range of 2.0 to $3.0 \%$ recommended by Nigerian raw materials research and development council (RMRDC, 2004). Therefore, the cassava inclusion levels of this study are very much desired.

\section{Carbohydrate}

The carbohydrate content of the composite flour samples increased $(73.42-79.23 \%)$ with increase in cassava inclusion due to significant $(\mathrm{P}<0.05)$ higher carbohydrate content of cassava $(82.42 \%)$ than wheat flour $(72.11 \%)$. Carbohydrate adds to weight and increases the bulk density and swelling index (Table 4).

Table 3. Proximate Composition of wheat-cassava composite flour blends (\%)

\begin{tabular}{l|ccccccc}
\hline Sample & Moisture c & Dry matter & CP & Crude fat & Ash & Crude fibre & Carbohydrate \\
\hline A & $8.49^{\mathrm{b}} \pm 0.02$ & $91.51^{\mathrm{a}} \pm 0.01$ & $12.24^{\mathrm{a}} \pm 0.02$ & $2.21^{\mathrm{a}} \pm 0.03$ & $1.09^{\mathrm{a}} \pm 0.12$ & $2.60^{\mathrm{a}} \pm 0.01$ & $72.11^{\mathrm{e}} \pm 0.07$ \\
B & $9.57^{\mathrm{a}} \pm 0.07$ & $90.44^{\mathrm{c}} \pm 0.09$ & $4.92^{\mathrm{d}} \pm 0.03$ & $0.71^{\mathrm{c}} \pm 0.03$ & $1.39^{\mathrm{a}} \pm 0.01$ & $2.47^{\mathrm{ab}} \pm 0.03$ & $82.42^{\mathrm{a}} \pm 0.03$ \\
C & $8.03^{\mathrm{ab}} \pm 0.01$ & $90.97^{\mathrm{bc}} \pm 0.01$ & $6.55^{\mathrm{c}} \pm 0.03$ & $1.66^{\mathrm{b}} \pm 0.02$ & $0.93^{\mathrm{b}} \pm 0.06$ & $2.41^{\mathrm{ab}} \pm 0.02$ & $74.44^{\mathrm{c}} \pm 0.01$ \\
D & $7.77^{\mathrm{ab}^{\mathrm{b}}} \pm 0.01$ & $91.20^{\mathrm{b}} \pm 0.01$ & $8.05^{\mathrm{b}} \pm 0.01$ & $2.08^{\mathrm{ab}} \pm 0.01$ & $0.75^{\mathrm{ab}} \pm 0.06$ & $2.53^{\mathrm{ab}} \pm 0.01$ & $73.42^{\mathrm{d}} \pm 0.01$ \\
E & $8.23^{\mathrm{ab}} \pm 0.02$ & $90.84^{\mathrm{bc}} \pm 0.01$ & $6.55^{\mathrm{c}} \pm 0.03$ & $0.98^{\mathrm{c}} \pm 0.03$ & $1.00^{\mathrm{b}} \pm 0.02$ & $2.20^{\mathrm{b}} \pm 0.03$ & $79.23^{\mathrm{b}} \pm 0.02$ \\
LSD & 1.09 & 0.231 & 2.055 & 0.31 & 0.071 & 0.59 & 1.34 \\
\hline
\end{tabular}

Values are means of triplicate determinations \pm standard deviation Means in the same column with different superscript are significantly different $(\mathrm{P}<0.05)$. $\mathrm{A}=100 \%$ Wheat, $\mathrm{B}=100 \%$ cassava, $\mathrm{C}=50 \%$ wheat $+50 \%$ cassava, $\mathrm{D}=70 \%$ wheat $+30 \%$ cassava and $\mathrm{E}=30 \%$ wheat $+70 \%$ cass ava. $\mathrm{CP}-$ crude protein 
Functional Properties of Wheat-Cassava Composite Flour Samples

The results are presented in Table 4.

Bulk density $(B D)$

Density is defined as the mass per unit volume of a substance which reveals the porosity and weight of a food material thereby making it criteria for choice of packaging materials (Onimawo and Akurbor, 2005). It is a physical attribute of the flour that determines also the mixing quality (Achinewhugar et al., 1998). The BD of the composite flours increased with increase in cassava inclusion may be because the BD of the cassava $(0.74 \mathrm{~g} / \mathrm{ml})$ is significantly $(\mathrm{p}<0.05)$ higher than that of wheat $(0.68 \mathrm{~g} / \mathrm{ml})$. Nonsignificant BD values between samples C $(50 \%$ wheat: $50 \%$ cassava) and D (70\% wheat: $30 \%$ cassava) could suggest maximum BD at between 50-70\% level of cassava inclusion, texture or mouth feel (Nasr and Abufoul, 2004). The BD is an advantage in complementary food formulation (Ugwu and Ukpabi, 2002), therefore flour samples with $50-70 \%$ cassava flour inclusion will make better complementary food.

Swelling index (SI)

The SI is a measure of how much water a food material can absorb depending on carbohydrate content. The SI increase (0.96-1.09\%) due to increase in cassava inclusion in the composite flour blends could be attributed to significant $(\mathrm{P}<0.05)$ higher SI of cassava flour $(1.13 \%)$ than wheat $(1.07 \%)$. Also, higher carbohydrate content (Echendu et al., 2004) as in table 3, variation in their protein content, degree of interaction with water and their conformational characteristics (McWattlers et al., 2003) may be another sources of the variation. Besides, WAC of cassava is also higher than wheat flour (Boye et al., 2011). Low SI of the entire composite flour samples is advantageous in chin-chin production as it will improve the crispness which enhances acceptability.

Oil absorption capacity (OAC)

This is an index of the ability of food material to absorb oil which helps to improve the mouth feel and retains flavour (Egan et al., 1981). The decrease in OAC of the composite flour blends with increase in cassava flour is a welcome development as it will save oil during chin-chin frying. The decrease could be due to significant $(\mathrm{P}<0.05)$ higher OAC of wheat flour $(1.38 \mathrm{~g} / \mathrm{g})$ than cassava $(1.27$ $\mathrm{g} / \mathrm{g})$. Based on this, it is economical to produce chin-chin with composite flour containing $50-70 \%$ cassava flour provided the acceptability is not compromised.

Water absorption capacity (WAC)

This is the ability of the flour blends to bind water which refers to the amount of water absorbed per gram depending on particle sizes (Boye et al., 2011). It correlates inversely with MC (Hoover, 2001). The increase in WAC with cassava flour increase due to significant $(\mathrm{P}<0.05)$ higher WAC of cassava flour $(2.42 \mathrm{~g} / \mathrm{g})$ than wheat $(1.16 \mathrm{~g} / \mathrm{g})$ is not desired. Higher WAC will bind most of the free water and may take longer time to achieve the desired crispness during chin-chin frying. Minimum WAC is required which is attainable with $<30 \%$ inclusion levels of cassava flour.

Emulsion capacity (EC)

The significant higher (43.21\%) EC of sample B (100\% cassava) than A (100\% wheat) with $28.12 \%$ could be the major source of EC increase in the composite flour samples with increase in cassava inclusion levels. Influence of cassava four on EC is maximum at $70 \%$ level of inclusion as the EC of samples C (50\% wheat $<50 \%$ cassava) and D $(70 \%$ wheat: $30 \%$ cassava) are not statistically different $(\mathrm{P}>0.05)$.

\section{Sensory Evaluation of Chin-Chin from Wheat- Cassava Composite Flour Blends}

The results are presented in Table 5.

Appearance

Appearance is an important sensory attribute of any food because the eyes eat first before rejecting or accepting. For baked products like chin-chin, brown colour resulting from caramelized sugar during frying is desired. The appearance scores of the chin-chin samples decreased with increase in cassava levels in the composite blends. The decrease which is lower than 8.20 from sample A $(100 \%$ wheat $)$ could be due to significant $(\mathrm{P}<0.05)$ higher score of sample A (100\% wheat) than 6.50 from B $(100 \%$ cassava). Therefore, chin-chin samples with higher wheat flour levels were mostly preferred as evident in higher score of sample D (7.35) compared to C (6.80) and E (6.85) without difference.

Table 4. Functional properties of Wheat-cassava composite flour samples

\begin{tabular}{l|ccccc}
\hline \multicolumn{1}{c|}{ Sample } & BD $(\mathrm{g} / \mathrm{ml})$ & S I $(\%)$ & OAC $(\mathrm{g} / \mathrm{g})$ & WAC $(\mathrm{g} / \mathrm{g})$ & $\mathrm{EC}(\%)$ \\
\hline A & $0.68^{\mathrm{b}} \pm 0.01$ & $1.07^{\mathrm{b}} \pm 0.01$ & $1.38^{\mathrm{a}} \pm 0.01$ & $1.16^{\mathrm{c}} \pm 0.01$ & $28.12^{\mathrm{d}} \pm 0.03$ \\
B & $0.74^{\mathrm{a}} \pm 0.01$ & $1.13^{\mathrm{a}} \pm 0.01$ & $1.27^{\mathrm{b}} \pm 0.01$ & $2.42^{\mathrm{a}} \pm 0.03$ & $43.21^{\mathrm{a}} \pm 0.01$ \\
C & $0.53^{\mathrm{d}} \pm 0.01$ & $0.98^{\mathrm{c}} \pm 0.01$ & $1.17^{\mathrm{c}} \pm 0.01$ & $1.13^{\mathrm{c}} \pm 0.01$ & $34.41^{\mathrm{c}} \pm 0.01$ \\
D & $0.51^{\mathrm{d} \pm 0.01}$ & $0.96^{\mathrm{c}} \pm 0.01$ & $1.29^{\mathrm{b}} \pm 0.01$ & $1.10^{\mathrm{c}} \pm 0.01$ & $27.41^{\mathrm{e}} \pm 0.01$ \\
E & $0.61^{\mathrm{c}^{\mathrm{c}} \pm 0.01}$ & $1.09^{\mathrm{b}} \pm 0.01$ & $1.16^{\mathrm{c}} \pm 0.01$ & $1.88^{\mathrm{b}} \pm 0.01$ & $39.48^{\mathrm{b}} \pm 0.01$ \\
LSD & 0.02 & $0.0^{2}$ & 0.03 & 0.03 & 0.72 \\
\hline
\end{tabular}

Values are means of triplicate determinations \pm standard deviation. Means in the same column with different superscript are significantly different $(\mathrm{P}$ $<0.05)$. LSD: Least Significant Difference. $A=100 \%$ wheat, $B=100 \%$ cassava, $C=50 \%$ wheat $+50 \%$ cassava, $D=70 \%$ wheat $+30 \%$ cassava, and $\mathrm{E}=30 \%$ wheat $+70 \%$ cassava.

Table 5. Sensory Evaluation of Wheat-cassava Chin-chin

\begin{tabular}{l|ccccc}
\hline \multicolumn{1}{c|}{ Samples } & Appearance & Crispiness & Taste & Aroma & O A \\
\hline A & $8.20^{\mathrm{a}} \pm 0.14$ & $7.60 \mathrm{a} \pm 0.14$. & $7.60^{\mathrm{a}} \pm 0.14$ & $7.15^{\mathrm{a}} \pm 0.07$ & $6.05^{\mathrm{a}} \pm 0.07$ \\
$\mathrm{~B}$ & $6.50^{\mathrm{e}} \pm 0.14$ & $5.30^{\mathrm{c}} \pm 0.14$ & $6.45^{\mathrm{b}} \pm 0.07$ & $6.35^{\mathrm{a}} \pm 0.07$ & $4.95^{\mathrm{b}} \pm 0.14$ \\
$\mathrm{C}$ & $6.80^{\mathrm{d}} \pm 0.14$ & $6.70^{\mathrm{a}} \pm 0.14$ & $6.65^{\mathrm{b}} \pm 0.07$ & $6.65^{\mathrm{a}} \pm 0.07$ & $5.30^{\mathrm{a}} \pm 0.14$ \\
$\mathrm{D}$ & $7.35^{\mathrm{b}} \pm 0.07$ & $6.60^{\mathrm{a}} \pm 0.14$ & $6.60^{\mathrm{b}} \pm 0.14$ & $6.50^{\mathrm{a}} \pm 0.14$ & $5.50^{\mathrm{a}} \pm 0.14$ \\
$\mathrm{E}$ & $6.85^{\mathrm{c}} \pm 0.07$ & $6.15^{\mathrm{a}} \pm 0.21$ & $6.40^{\mathrm{b}} \pm 0.14$ & $6.75^{\mathrm{a}} \pm 0.07$ & $5.10^{\mathrm{a}} \pm 0.07$ \\
LSD & 1.22 & 1.00 & 2.28 & 1.20 & 1.32 \\
\hline
\end{tabular}

Values are means of triplicate determinations+ standard deviation. Means in the same column with different superscript are significantly difference $(\mathrm{P}<0.05)$. $\mathrm{A}=100 \%$ wheat, $\mathrm{B}=100 \%$ cassava, $\mathrm{C}=50 \%$ wheat $: 50 \%$ cassava, $\mathrm{D}=70 \%$ wheat: $30 \%$ cassava, and $\mathrm{E}=30 \%$ wheat $: 70 \%$ cassava. 


\section{Crispiness}

Crispiness is a major desirable quality of chin-chin as nobody desires soggy chin-chin which is regarded as spoilt. The crispiness of the chin-chin from the composite flour blends decreased (6.70-6.15) compared to sample A (7.60) with increase in inclusion levels of cassava. This could be ascribed to significant $(\mathrm{P}<0.05)$ higher $\mathrm{MC}$ of cassava $(82.42 \%)$ than wheat flour $(72.11 \%)$ as shown in table 3 which may have soften the chin-chin and diluted the protein strength of the wheat flour. This is evident in the least acceptability score of chin-chin from $100 \%$ cassava flour (5.30). Maximum decrease was as from 50-100\% cassava inclusion since there is no significant $(\mathrm{P}>0.05)$ crispiness variation between samples $\mathrm{C}$ and D. Minimum decrease was at $30 \%$ and lower.

\section{Taste}

Taste is an important sensory attribute that measures the extent flavor is perceived on the taste buds of the tongue (Iwe, 2007).It is the main criterion that decides product rejection or acceptability. Though the taste scores of the chin-chin from the composite flour blends decreased slightly with inclusion levels of cassava, there was no significant $(p>0.05)$ variation in all the entire chin-chin samples which implied no noticeable effect.

\section{Aroma}

Just like in taste, there was no significant $(\mathrm{P}>0.05)$ aroma variation in the entire chin-chin samples which may mean no meaningful effect of the cassava inclusion levels used in this study on their taste and aroma.

\section{Overall acceptability}

The results show that increasing or decreasing cassava inclusion levels in the composite flour dose not have any significant $(\mathrm{P}>0.05)$ variation in overall acceptability of chin-chin produced from them despite the slight decrease.

\section{Conclusion}

This study revealed that the functional properties of the wheat-cassava composite flour blends, nutrient content and the acceptability of chin-chin samples produced from them varied with the blends. With increase in cassava flour levels in the composite blends, there were increases in moisture, carbohydrate, ash, bulk density, swelling index, water absorption capacity and emulsion capacity of the composite flour blends. Conversely, there were decreases in dry matter, protein, fat, fibre and oil absorption capacity. All the proximate compositions of the chin-chin decreased except moisture content and carbohydrate. There was no significant influence of the flour blends on the acceptability of the chin-chin. Therefore, chin-chin made from wheatcassava composite flour were generally accepted, but $<30 \%$ levels of cassava inclusion in the composite blends will improve the nutrient and acceptability levels of the chin-chin better most especially at lower levels.

\section{Acknowledgement}

The authors were grateful to the Department of Food Science and Technology, Michael Okpara University of Agriculture Umudike, Nigeria for their supply of the reagents used for the analyses and analytical space.

\section{References}

Achinewhugar SC, Barber LI, Ijeoma IO. 1998. Physicochemical properties and reification of selected cassava cutovers in River state. Plant Food for Human Nutrition, 52: 133140.

Adams ML, Lombi E, Zhao FJ, McGrath SP. 2002. Evidence of low selenium concentrations in UK bread-making wheat grain. Journal of the Science of Food and Agriculture, 82: 1160-1165.

Adegunwa MO, Ganiyu AA, Bakare H A, Adeborale A A. 2014. Quality evaluation of composite millet-wheat Chin-chin. Agricultural and Biology Journal of North America. ISSN. 2151-7517.

Aro SO, Aletor VA, Tewe OO, Fajemisin AN, Usifo B, Falowo AB. 2008. Preliminary investigation on the nutrients, antinutrients and mineral composition of microbial fermented cassava starch residues. In: Proceedings of the 33rd Annual Conference of Nigerian Society of Animal Production (NSAP), Ayetoro, Ogun State, Nigeria. 21st May, 2008. pp. $86-92$.

Anon A. 2000. Reports on symposiums on composite flours, 1976 - 2000, particular sorghum and millet. International Association for Cereal Science and Technology, 1ICC,

AOAC 2010. Official Methods of Analysis. $18^{\text {th }}$ Edition, Association of Official Analytical Chemists; Washington D.C., (USA).

Boye JI, Zubair F. 2011. Water holding capacity In: Pulse foods from http://www.sciencedirect.com/topic/agricultural and biological-sciences/water-binding/pdf

Echendu CA, Onimawo IA, Somtochi A, 2004. Production and evaluation of doughnuts and biscuits from maize - pigeon pea flour blends. Nigerian Food Journal, (22): 147 - 153.

Egan H, Kirk, RS, Sawyer R. 1981. Pearson's chemical analysis of foods, $8^{\text {th }}$ Edi. Essexi Longman Scientific and Technical; (UK).

Falade K, Akingbala J, 2010. Utilization of cassava for food. Food Reviews International, 27:1, 51-83. Fellows PJ. 1997. Frying In: Food processing Technology: Principles and practice. Woodheat Publishing Series in Food Science and Technology. Pp 331-339.

Hoover R. 2001. Composition, molecular structure, and physicochemical properties of tuber and root starches: A Review. Carbohydrate Poly, 45: 253-267.

Iwe M O. 2002. Handbook of Sensory Methods and Analysis. Rojoint Communication. Pp. 80-90.

Iwe M.O. 2007. Current Trends in Sensory Evaluation of Food. Published by Rojoint Communication Services Ltd.106-137.

James CJ. 1995. The analytical chemistry of foods. Chapman and Hall Press, New York, pages: 86 - 89.

Mepba HD, Eboh L, Nwaojigwa, SU. 2007. Chemical composition, functional and baking properties of wheatplantain composite flours. African Journal of food, Agriculture, Nutrition and Development, 7: 1-22.

McWattlers KH, Ouedraogo, JB, Resurrection, AVA, Hung Y, Philips RD. 2003. Physical and sugar content of cookies containing mixtures of wheat, Forio (Digitaria exilis) and Cowpea (Vigna unguiculata) flours. International Journal of Food Science and Technology, 38: 403 - 410.

Nasr SI, Abufoul A, 2004. Using free fat watermelon (Citrullus vuglgaris) seed kernels in preparing high protein biscuits. AlAzhar University Gaza, Gaza Palestine. 7: 45-54.

Nzelu IC, Nwosu UL, Onwurah CO, 2012. Food analysis: Principles and practice. Fergu Nwankwo Printing Service, Enugu. Pp. 55.

Olaoye OA, Ubbor SC, Okakpu CJ. 2016. Use of composite flours of wheat and white beans (Phaseolus vulgaris) in bread making: influence on quality indices. Applied Science Report, (C) PSCI Publications.15 (3): 148-154. 
Olaoye OA, Onilude AA, Oladoye CO. 2007. Breadfruit flour in biscuit making. African Journal of Food Science, 20-23.

Oluwamukomi MO, Oluwalana IB, Akinbowale OF. 2010. Physicochemical and sensory properties of wheat cassava composite biscuit enriched with soy flour. African Journal of Food Science, 5 (2): 50 - 56.

Onimawo AI, Akubor PI. 2005. Functional properties of food. In: Food Chemistry. Integrated approach with biochemical background. Benin City, Nigeria, Ambik Press Limited, Pp 208-221.

Onwuka GI, 2018. Food Analysis and instrumentation theory and practice. $2^{\text {nd }}$ edt Naphthali: Prints.. 104-121.

RMRDC, 2004. RMRDC Workshop. Cassava. In: Report on Survey of Selected Agricultural Raw Materials in Nigeria. Raw Materials Research and Development Council (RMRDC), Abuja. Nigeria.
Sanni LO, Adebowale AA, Tafa SO. 2006. Proximate, functional, pasting and sensory qualities of instant yam flour. A paper presented at the (4 1STR Symposium, central tuber crops the research Institute, Trivadrum, kerala State. India.

Topping D. 2007. Cereal complex carbohydrates and their contribution to human health. Journal of Cereal Science, 46:220-229.

Thongkratok R, Khempaka S, Molee W. 2010. Protein enrichment of cassava pulp using microorganisms' fermentation techniques for use as an alternative animal feedstuff. Journal of Animal and Veterinary Advances, $9(22): 2859-62$

Ugwu E, Ukpabi UJ. 2002. Potential of soy cassava flour processing to sustain increasing cassava production in Nigeria. Outlook on Agriculture, 31(2): 129 - 133. 